\title{
THE EFFECTS OF CLIMATE CHANGE ON DECOMPOSITION PROCESSES IN ANDEAN PARAMO ECOSYSTEM-SYNTHESIS, A SYSTEMATIC REVIEW
}

\author{
GUTIÉRREZ-SALAZAR, P. ${ }^{1 *}$ - MEDRANO-VIZCAÍNO, P. ${ }^{2}$ \\ ${ }^{1}$ Grupo de Investigación Ambiental para el Desarrollo Sustentable (GIADES) Universidad \\ Politécnica Salesiana, Rumichaca y Morán Valverde s/n, Quito, Ecuador \\ (phone: +593-2-396-2900; fax: +593-2-396-2800) \\ ${ }^{2}$ Centro de Biología, Laboratorio de Zoología, Universidad Central del Ecuador, \\ Av. Universitaria 170129, Quito, Ecuador \\ (phone/fax: +593-2-252-8810) \\ *Corresponding author \\ e-mail:pgutierrez@ups.edu.ec; phone: +593-2-396-2900
}

(Received $8^{\text {th }}$ Nov 2018; accepted $5^{\text {th }}$ Mar 2019)

\begin{abstract}
The paramo is a high mountain ecosystem with cold and humid climate, it has high amount of sunlight and cloudiness, furthermore, organic matter has low decomposition rates, hence, leaf litter degradation gets $40 \%$ per year as maximum. In the last 70 years, the air temperature near the surface of the Tropical Andes has increased significantly up to $0.34{ }^{\circ} \mathrm{C} / \mathrm{decade}$. In the same region, it is estimated that in this century the average temperature will vary from $\left\langle+1.60{ }^{\circ} \mathrm{C}\right.$ to $>+2.61{ }^{\circ} \mathrm{C}$, which exceeds the threshold of natural climatic variability. On the other hand, although precipitation along the Andes has not shown an increase or diminish pattern between 1955 and 1994, it is projected that by the year 2100, it will decrease in the outer tropics and will increase in the interior tropics. In this paper, we discuss how the decomposition of organic matter in paramo areas is influenced by climate change and analyze how current trends of variation in temperature are projected to affect ecosystem processes. Previous studies have determined that the increase of the atmospheric temperature (as long as the humidity remains stable or increases), generates higher decomposition rates, so that an increase of $1{ }^{\circ} \mathrm{C}$ in the atmospheric temperature would also mean an increase in the rate of decomposition of up to $10 \%$. These changes would cause the release of the carbon accumulated in the soil to the atmosphere as $\mathrm{CO}_{2}$, which would be a determining factor for climate change.
\end{abstract}

Keywords: $\mathrm{CO}_{2}$, global warming, greenhouse gases, organic matter, temperature

\section{Introduction}

The paramo is a high mountain ecosystem in the humid tropic, it is located in the Andes, the Afroalpine zone, Indonesia and Papua New Guinea (Buytaert et al., 2011). This ecosystem has a cold and humid climate, with high amount of sunlight and cloudiness, its temperature gets an anual average of $10^{\circ} \mathrm{C}$ at $3000 \mathrm{~m}$ a.s.l. and reaches $0{ }^{\circ} \mathrm{C}$ at $4600 \mathrm{~m}$ a.s.1. (Llambí et al., 2013). Climate conditions in this region are variable, so that, the daily thermal amplitude ranges between 10 and $15^{\circ} \mathrm{C}$ in the air and in clear days it reaches $50{ }^{\circ} \mathrm{C}$ in the soil surface (Llambí et al., 2013), while precipitation ranges between $700 \mathrm{~mm}$ to $3000 \mathrm{~mm} /$ year (Llambí et al., 2013). Despite climate conditions, there is a high biological diversity and endemism, approximately 3400 species of vascular plants inhabit the paramo of South America and $60 \%$ are endemic (Luteyn, 1999; Rangel Churio, 2000).

Paramo is considered as a carbon sink, it can store a higher quantity of carbon per hectare than tropical forests (Hofstede et al., 2014). It accumulates between 119 and 
397 tons per hectare (t/ha) in 0 to $40 \mathrm{~cm}$ depth, (Castañeda-Martín and Montes-Pulido, 2017) meanwhile bofedales show an approximate accumulation of carbon of $30 \mathrm{~kg} \mathrm{~m}^{2}$ (Segnini et al., 2010).

In addition to carbon storage in mineral soils, there is also accumulation of organic matter in peat bogs (Hofstede et al., 2014). In the north of Ecuador, it was estimated the average organic matter quantity in two peat bogs is $1282 \mathrm{t} / \mathrm{ha}$ (Hribljan et al., 2016), with an accumulation of $4.6 \mathrm{t} / \mathrm{ha} /$ year (Chimner and Karberg, 2008). Moreover, paramo vegetation contributes with fresh organic matter to soil, which means about 6 to 13 t/ha/year (Escobedo-Urquizo, 1980).

On the other hand, despite the importance of paramo through supplying environmental services such as water provision, climate regulation and carbon accumulation in soil), it is one of the more vulnerable terrestrial ecosystems to global climate change (Buytaert et al., 2011; Ruiz et al., 2008). It is found within alpine life zones that are highly sensitive to climate change because its distribution has been closely related to temperature and precipitation patterns (Cuesta et al., 2017). Likewise, if high mountain ecosystems lose humidity and the annual average temperature gets higher, it would cause an increasing conversion of organic matter into atmospheric carbon, which would favor climate change conditions (Buytaert et al., 2011; Jones et al., 2005).

In the same way, an increasing environmental temperature would augment the evaporation and evapotranspiration, altering the precipitation patterns (Arnell, 1999), which could cause a deficit in water supply to populations that depend directly on water from the paramo, like Quito and Bogotá (Buytaert et al., 2011).

In the Tropical Andes region, environmental temperature has shown an increasing trend of $0.11^{\circ} \mathrm{C} /$ decade from 1939 to 1998 and $0.34{ }^{\circ} \mathrm{C} /$ decade from 1974 to 1998 (Buytaert et al., 2014). Regarding precipitation, changes have not been significant in all the region (Vuille et al., 2003). Nevertheless, records from weather stations indicate higher precipitation levels for Ecuador, but lower levels Peru and Bolivia (Buytaert et al., 2014).

The aim of this paper is to comprehensively review the state of knowledge of decomposition and climate change in paramo ecosystems to understand the consequences on ecological processes, and to obtain ideas to develop strategies to mitigate the effects of climate change.

\section{Decomposition and climate projections}

Climate projections for the Andean Region show an increase in the average temperature up to $5{ }^{\circ} \mathrm{C}$ on the eastern flank of Ecuador and Peru (Herzog et al., 2012). Precipitation has a mixed pattern: increasing in the eastern and western flanks and decreasing in the inter Andean region up to 15\% (Vuille et al., 2008; Urrutia, 2008; IPCC, 2013; Kirtman et al., 2013)

Predictions of global climate models and regional models for the Andean region have a high range of uncertainty due to lack of meteorological stations at altitudes above $3000 \mathrm{~m}$ a.s.l. (Buytaert et al., 2014). However, these projections are important to analyze the effects that climate change could have on the stability of ecosystems, environmental services and ecological processes (IPCC, 2007), especially because climate change has the capacity to alter physical and biological processes, threatening survival of endangered species (Carroll et al., 2015). For example, many studies have 
focused on assessing the influence of climate change on certain species, and some results suggest that climate change conditions could lead to changes in communities composition, populations declines, range shifts, changes in relative abundance and high extinction risks (Gillings et al., 2015; Bush et al., 2016; Wang et al., 2016; Dalamsuren et al., 2017; Pecl et al., 2017; Urban, 2015).

Decomposition comprises physical and chemical processes that allow the reduction of macromolecules into their essential components (Aerts, 1997) generating $\mathrm{CO}_{2}$ and soluble forms of nutrients that can be recycled in plants and other organisms (Cronan, 2018). Most of the organic matter that is involved in this process in terrestrial ecosystems are derived from plants (leaf litter, stems, root exudates) (Carter et al., 2007), while influential factors are: weather, chemical composition of leaf litter and soil organisms (Coûteaux et al., 1995; Aerts, 1997, 2006).

Concerning climate, temperature and soil moisture (commonly referred to as climate decomposition index) have shown to be the best predictors of decomposition rates (Parton et al., 2007)), they can slow or accelerate organic matter decomposition (Davidson and Janssens, 2006; Coûteaux et al., 2002).

As shown, it is evident that decomposition is different in every ecosystem (Zhang et al., 2008; Djukic et al., 2018). This was verified by assessing decomposition rates in three regions of the planet: Tropical, Temperate and Mediterranean, the average values obtained per year were $2.33,0.36,0.35$ respectively, showing that in humid tropics the decomposition rate is higher than in the temperate and Mediterranean zones (Aerts, 1997).

Regarding chemical composition of organic matter, leaf litter quality has a significant and predictable influence on the temperature sensitivity of organic matter decomposition (Fierer et al., 2005), besides, it is also important during decomposition phases due to its effects on humus formation (Coûteaux et al., 1995). Likewise, certain plant species have low decomposition rates compared to their high lignin content (Zhang et al., 2008) or presence of polyphenols that inhibit degradation (Hättenschwiler et al., 2005).

Although bacteria and fungi are the main decomposer organisms, macroinvertebrates also play a fundamental role, starting the process of litter crushing (Ulyshen, 2016). While more organisms participate in degrading organic matter, an increase in the rate of decomposition is generated (Smith and Bradford, 2003; Wall et al., 2008).

Given the sensitivity of decomposition to climatic conditions, it is understood that global warming will increase litter decomposition rates, through direct effects and through indirect effects on leaf litter quality and soil organisms (Aerts, 2006).

\section{Organic matter decomposition in paramo ecosystems}

Decomposition process in paramo ecosystems is mainly limited by atmospheric temperature that shows a high daily variation (temperature differences higher than $20{ }^{\circ} \mathrm{C}$ between night and day are common) (Hofstede et al., 2014). On the other hand, in paramo ecosystems with volcanic origins, an important factor is the presence of vesicles that organic matter generates with aluminum from volcanic ashes, turning into chemical complexes that are resistant to organisms degradation (Hofstede et al., 2003, 2014; Bottner et al., 2006).

As mentioned before, although bacteria communities are important for decomposition (Bottner et al., 2006; Pansu et al., 2004), invertebrates also play an 
important role in the disintegration of organic matter (Ulyshen, 2016), its diversity is associated with the presence of vegetation (Ewers et al., 2015) and, richness of soil fauna together with climate are associated with decomposition rates globally (Wall et al., 2008).

Concerning leaf litter quality, decomposition process in paramo do not depend on lignin concentration. As paramo vegetation is mainly composed by rosettes, cushions, shrubs and herbs (Ramsay and Oxley, 1997) it is not woody, then its lignin content would be low (Coûteaux et al., 1995). Nevertheless, some species contain aromatic resins that decrease the rate of decomposition (Smith, 1981).

Several studies have analyzed decomposition processes in High Andean ecosystems focusing research in: 1) the effect of human activities on decomposition (Jiang et al., 2015; Ossola et al., 2016; Urbina and Benavides, 2015), 2) influence of altitude in organic matter decomposition (Coûteaux et al., 2002; Röderstein et al., 2005) and 3) factors that influence on organic matter decomposition (Bottner et al., 2006; Pansu et al., 2004, 2007; Ibrahim et al., 2015; Martinez et al., 2007; Pinos et al., 2017).

\section{Climate change and organic matter decomposition}

It is expected that in this century, the increasing $\mathrm{CO}_{2}$ concentrations and other greenhouse gases in Earths atmosphere cause warmer surface temperatures and changes in precipitation patterns (IPCC, 2013). These environmental changes could affect the carbon cycle, modifying the function and ecosystem services (Dukes et al., 2005).

In order to determine the influence of climate change on ecosystems, models have been generated to simulate the response of the decomposition process to climate change, which have made it possible to determine that an increasing atmospheric temperature will produce a decrease of 54 gigatons (Gt) in the global carbon stock of the soil for 2100 (Jones et al., 2005).

In addition, some studies have shown the influence of climate change on the decomposition process, so that, it was determined that the increase in soil temperature accelerates the decomposition process in Arctic soils (Robinson et al., 1995), while in other study, researchers determined that the decomposition process is limited by moisture in the xeric zones and in the mesic zone it is determined by temperature (Shaw and Harte, 2001). On the other hand, a research using experimental microcosms, determined that the change of climatic conditions in a short term (from days to decades) strongly influences the decomposition process of litter (Strickland et al., 2015).

\section{Climate change and organic matter decomposition in Andean paramos}

In the Tropical Andes, atmospheric temperature near surface has increased significantly in the last 70 years (Vuille et al., 2008). A regression analysis with ordinary least squares indicates a warming of $0.10{ }^{\circ} \mathrm{C} /$ decade and a general temperature increase of $0.68{ }^{\circ} \mathrm{C}$ since 1939 (Vuille et al., 2008). Furthermore, it is suggested that in this century, in a scenario with a balanced use of fossil fuels and energies of non-fossil origin (scenario of $\mathrm{A} 1 \mathrm{~B}$ emissions), the temperature for Tropical Andes region will probably vary from $<+1.60{ }^{\circ} \mathrm{C}$ to $>+2.61^{\circ} \mathrm{C}$, exceeding the threshold of natural climatic variability $\left(+1.78^{\circ} \mathrm{C}\right)$ (Ruiz-Carrascal et al., 2017).

In the case of precipitation, there are no reports of increasing or decreasing patterns at a regional levels between 1955 and 1994 (Vuille et al., 2003). For the period 20712100 in a scenario of A1 emissions (rapid economic growth at global level, a maximum 
of the worlds population by the middle of the century and a rapid introduction of new and more efficient technologies) precipitation along the Andes would present a mixed pattern of increase and decrease that goes from -50 to $250 \%$ (Urrutia, 2008). In general terms, it is projected that for the second half of the 20th century, rainfall will decrease in the outer tropics and increase in the interior tropics (Urrutia, 2008; Vuille et al., 2008).

According climatic projections for the Andean Region $\left(10^{\circ}-20^{\circ} \mathrm{S}\right)$ (Herzog et al., 2012), with a high population growth (scenario of A2 emissions), an increase in average temperature and precipitation would occur by the end of the 21 st century, for example, on the western flank of the northern Peru, the increase in rainfall would be up to $70 \%$, while in the Inter Andean region of Colombia a decrease of up to $15 \%$ will occur; and an increase of $5{ }^{\circ} \mathrm{C}$ of temperature is projected in the eastern flank of Ecuador and Peru (Herzog et al., 2012).

In the Fifth Report of the Intergovernmental Panel on Climate Change (IPCC) results of projections for an immediate climate change (Period 2016-2035 regarding 19862005 in RCP4.5 scenario comparable with B1) in the Andean Region suggest an increase in temperature of up to 1.5 and an increase in precipitation of up to $10 \%$ (IPCC, 2013; Kirtman et al., 2013).

An eventual change in the temperature and humidity of the paramo soil would lead to a modification in decomposition processes. It is necessary to consider that high Andean ecosystems would be more sensitive than the humid tropical forest in conditions of increasing temperature, with a trend to increase the rate of decomposition, therefore carbon sink ecosystemic services would be affected. In addition, it is important to mention that it is unknown how microbial communities would participate in different climate change scenarios (Hofstede et al., 2014).

While preparing this document, a considerable amount of information about the impact of climate change on soil and biodiversity was found. However, in the few investigations found about the effect of climate change on the decomposition process in the paramo (Appendix 2), it was determined that the increase in atmospheric temperature accelerates decomposition rates.

Climate change in the Andean Region will increase decomposition and mineralization rates up to $10 \%$ (Salinas et al., 2011). In situ studies through an altitudinal gradient, have allowed to project the changes of climatic conditions, being able to determine that the decomposition rate in the Andean paramo will be influenced by an increase in the air temperature (Espín Meneses, 2012). Furthermore, even if atmospheric temperature increases, when humidity decreases, decomposition rate decreases too, it happens not only due to its direct incidence on degradation process but also because it alters abundance and richness of decomposing organisms (Looby and Treseder, 2018).

\section{Conclusions}

Despite the importance of decomposition process in the functioning of ecosystems and although since 1939 there have been alarming reports of a general increase in temperature of $0.68{ }^{\circ} \mathrm{C}$ for Tropical Andes region, there are few studies about the influence of climate change on decomposition in paramo areas, in other words, knowledge about this issue is currently scarce.

Decomposition process at biomes scale is controlled by climate, then climate change can directly affect the functioning of ecosystems. Studies about this issue mention that 
the rate of decomposition increases with higher temperatures (only when humidity is maintained or increased), then an increase of $1{ }^{\circ} \mathrm{C}$ in atmospheric temperature could cause the decomposition rate to increase by up to $10 \%$.

Projections suggest that in this century, paramo areas will have constant humidity and increasing temperatures exceeding $2{ }^{\circ} \mathrm{C}$. According to this climate scenario, the rate of decomposition would increase, causing the carbon accumulated in the organic matter of the soil to be emitted back into the atmosphere

Exploring studies about the effect of climate change in decomposition rates in paramo ecosystems is still a challenge, we need to conduct experimental research in order to understand how ecological processes work in this ecosystem. Generating knowledge will provide people new ideas to mitigate effects of climate change for present and future scenarios.

\section{REFERENCES}

[1] Aerts, R. (1997): Climate, leaf litter chemistry and leaf litter decomposition in terrestrial ecosystems: a triangular relationship. - Oikos 79: 439-449.

[2] Aerts, R. (2006): The freezer defrosting: global warming and litter decomposition rates in cold biomes. - Journal of Ecology 94: 713-724.

[3] Arnell, N. W. (1999): Climate change and global water resources. - Global Environmental Change 9: S31-S49.

[4] Bottner, P., Pansu, M., Sarmiento, L., Hervé, D., Callisaya-Bautista, R., Metselaar, K. (2006): Factors controlling decomposition of soil organic matter in fallow systems of the high tropical Andes: A field simulation approach using 14C-and 15N-labelled plant material. - Soil Biology and Biochemistry 38: 2162-2177.

[5] Buytaert, W., Cuesta-Camacho, F., Tobón, C. (2011): Potential impacts of climate change on the environmental services of humid tropical alpine regions. - Global Ecology and Biogeography 20: 19-33.

[6] Buytaert, W., Sevink, J., Cuesta, F., Cuesta, F., LLambi, L., Posner, J. (2014): Climate Change: The New Threat for Paramos. Advances in Research for Conservation of Andean Paramos [Spanish]. - CONDESAN, Lima.

[7] Bush, A., Mokany, K., Catullo, R., Hoffmann, A., Kellermann, V., Sgrò, C., ... Ferrier, S. (2016): Incorporating evolutionary adaptation in species distribution modelling reduces projected vulnerability to climate change. - Ecology Letters 19: 1468-1478.

[8] Carroll, M. J., Heinemeyer, A., Pearce-Higgins, J. W., Dennis, P., West, C., Holden, J., ... Thomas, C. D. (2015): Hydrologically driven ecosystem processes determine the distribution and persistence of ecosystem-specialist predators under climate change. Nature Communications 6: 7851.

[9] Carter, D. O., Yellowlees, D., Tibbett, M. (2007): Cadaver decomposition in terrestrial ecosystems. - Naturwissenschaften 94: 12-24.

[10] Castañeda-Martín, A. E., Montes-Pulido, C. R. (2017): Carbon stored in Andean Paramo [Spanish]. - Entramado 13: 210-221.

[11] Chimner, R., Karberg, J. (2008): Long-term carbon accumulation in two tropical mountain peatlands, Andes Mountains, Ecuador. - Mires \& Peat 3.

[12] Coûteaux, M.-M., Bottner, P., Berg, B. (1995): Litter decomposition, climate and litter quality. - Trends in Ecology \& Evolution 10: 63-66.

[13] Coûteaux, M., Sarmiento, L., Bottner, P., Acevedo, D., Thiéry, J. (2002): Decomposition of standard plant material along an altitudinal transect $(65-3968 \mathrm{~m})$ in the tropical Andes. - Soil Biology and Biochemistry 34: 69-78.

[14] Cronan, C. S. (2018): Cycling of Organic Matter. - Ecosystem Biogeochemistry. Springer, Cham. 
[15] Cuesta, F., Muriel, P., Llambí, L. D., Halloy, S., Aguirre, N., Beck, S., Carilla, J., Meneses, R. I., Cuello, S., Grau, A. (2017): Latitudinal and altitudinal patterns of plant community diversity on mountain summits across the tropical Andes. - Ecography 40: 1381-1394.

[16] Davidson, E. A., Janssens, I. A. (2006): Temperature sensitivity of soil carbon decomposition and feedbacks to climate change. - Nature 440: 165.

[17] Djukic, I., Kepfer-Rojas, S., Schmidt, I., Larsen, K., Beier, C., Berg, B., Verheyen, K., Caliman, A., Paquette, A., Gutiérrez-Girón, A. (2018): Early stage litter decomposition across biomes. - Science of the Total Environment 628: 1369-1394.

[18] Dukes, J. S., Chiariello, N. R., Cleland, E. E., Moore, L. A., Shaw, M. R., Thayer, S., Tobeck, T., Mooney, H. A., Field, C. B. (2005): Responses of grassland production to single and multiple global environmental changes. - PLoS Biology 3: e319.

[19] Dulamsuren, C., Hauck, M., Kopp, G., Ruff, M., Leuschner, C. (2017): European beech responds to climate change with growth decline at lower, and growth increase at higher elevations in the center of its distribution range (SW Germany). - Trees 31: 673-686.

[20] Escobedo-Urquizo, J. (1980): The soils of Paramos. Pedogenetic study in the High Andes of northern Peru [French]. - Doctoral Thesis, Faculty of Agricultural Sciences of Gembloux, Gembloux University, Belgium.

[21] Espín Meneses, S. A. (2012): Altitudinal patterns of litter decomposition in two localities under different climate conditions [Spanish]. - Bachelor's Thesis, Universidad San Francisco de Quito, Ecuador.

[22] Ewers, R. M., Boyle, M. J., Gleave, R. A., Plowman, N. S., Benedick S, Bernard H, Bishop, T. R., Bakhtiar, E. Y., Chey, V. K., Chung AY (2015): Logging cuts the functional importance of invertebrates in tropical rainforest. - Nature Communications 6 : 6836.

[23] Fierer, N., Craine, J. M., McLauchlan, K., Schimel, J. P. (2005): Litter quality and the temperature sensitivity of decomposition. - Ecology 86: 320-326.

[24] Gillings, S., Balmer, D. E., Fuller, R. J. (2015): Directionality of recent bird distribution shifts and climate change in Great Britain. - Global Change Biology 21: 2155-2168.

[25] Herzog, S. K., Martinez, R., Jørgensen, P. M., Tiessen, H. (2012): Climate Change and Biodiversity in the Tropical Andes [Spanish]. - Inter-American Institute for Global Change Research (IAI), Montevideo and Scientific Committee on Problems of the Environment (SCOPE).

[26] Hofstede, R., Calles, J., López, V., Polanco, R., Torres, F., Ulloa, J., Vásquez, A., Cerra, M. (2014): Andean Paramos. What Do We Know? State of Knowledge on the Impact of Climate Change in Paramo Ecosystem [Spanish]. - UICN, Quito, Ecuador.

[27] Hribljan, J. A., Suárez, E., Heckman, K. A., Lilleskov, E. A., Chimner, R. A. (2016): Peatland carbon stocks and accumulation rates in the Ecuadorian páramo. - Wetlands Ecology and Management 24: 113-127.

[28] Hättenschwiler, S., Tiunov, A. V., Scheu, S. (2005): Biodiversity and litter decomposition in terrestrial ecosystems. - Annual Review of Ecology, Evolution, and Systematics 36: 191-218.

[29] Ibrahim, H., Brahim, N., Hatira, A. (2015): Modelling carbon turnover through the microbial biomass in soil. - Journal of Research in Environmental and Earth Science 3: $105-117$.

[30] IPCC (2007): Climate Change 2007: Synthesis Report [Spanish]. - Contribución de los Grupos de trabajo I, II y III al Cuarto Informe de evaluación del Grupo Intergubernamental de Expertos sobre el Cambio Climático. Ginebra, Suiza.

[31] IPCC (2013). Appendix I: Atlas of Global and Regional Climate Projections (by van Oldenborgh, G. J., Collins, M., Arblaster, J., Christensen, J. H., Marotzke, J., Power, S. B., Rummukainen, M., Zhou, T.). - In: Stocker, T. F., Qin, D., Plattner, G.-K. , Tignor, M., Allen, S. K., Boschung, J., Nauels, A., Xia, Y., Bex, V., Midgley, P. M. (eds.) Climate Change 2013: The Physical Science Basis. Contribution of Working Group I to 
the Fifth Assessment Report of the Intergovernmental Panel on Climate Change. Cambridge University Press, Cambridge, UK and New York.

[32] Jiang, C., Xiong, L., Wang, D., Liu, P., Guo, S., Xu, C. Y. (2015): Separating the impacts of climate change and human activities on runoff using the Budyko-type equations with time-varying parameters. - Journal of Hydrology 522: 326-338.

[33] Jones, C., McConnell, C., Coleman, K., Cox, P., Falloon, P., Jenkinson, D., Powlson, D. (2005): Global climate change and soil carbon stocks; predictions from two contrasting models for the turnover of organic carbon in soil. - Global Change Biology 11: 154-166.

[34] Kirtman, B., Power, S., Adedoyin, A., Boer, G., Bojariu, R., Camilloni, I., Doblas-Reyes, F., Fiore, A., Kimoto, M., Meehl, G. (2013): Near-Term Climate Change: Projections and Predictability. - In: Stocker, T. F., Qin, D., Plattner, G.-K., Tignor, M., Allen, S. K., Boschung, J., Nauels, A., Xia, Y., Bex, V., Midgley, P. M. (eds.) Climate Change 2013: The Physical Science Basis. Contribution of Working Group I to the Fifth Assessment Report of the Intergovernmental Panel on Climate Change. Cambridge University Press, Cambridge, UK, New York.

[35] Llambí, L. D., Sarmiento, L., Rada, F. (2013): The evolution of ecological research in the paramos of Venezuela: Multiple visions of a unique ecosystem [Spanish]. - Instituto Venezolano de Investigaciones Científicas, Caracas.

[36] Looby, C. I., Treseder, K. K. (2018): Shifts in soil fungi and extracellular enzyme activity with simulated climate change in a tropical montane cloud forest. - Soil Biology and Biochemistry 117: 87-96.

[37] Luteyn, J. L. (1999): Páramos: A Checklist of Plant Diversity, Geographical Distribution and Botanical Literature. - The New York Botanic Garden, New York.

[38] Martinez, E., Duque, P., Wolff, M. (2007): Succession pattern of carrion-feeding insects in Paramo, Colombia. - Forensic Science International 166: 182-189.

[39] Ossola, A., Hahs, A. K., Nash, M. A., Livesley, S. J. (2016): Habitat complexity enhances comminution and decomposition processes in urban ecosystems. - Ecosystems 19: 927941.

[40] Pansu, M., Bottner, P., Sarmiento, L., Metselaar, K. (2004): Comparison of five soil organic matter decomposition models using data from a $14 \mathrm{C}$ and $15 \mathrm{~N}$ labeling field experiment. - Global Biogeochemical Cycles 18.

[41] Pansu, M., Sarmiento, L., Metselaar, K., Hervé, D., Bottner, P. (2007): Modelling the transformations and sequestration of soil organic matter in two contrasting ecosystems of the Andes. - European Journal of Soil Science 58: 775-785.

[42] Parton, W., Silver, W. L., Burke, I. C., Grassens, L., Harmon, M. E., Currie, W. S., ... Fasth, B. (2007): Global-scale similarities in nitrogen release patterns during long-term decomposition. - Science 315: 361-364.

[43] Pecl, G. T., Araújo, M. B., Bell, J. D., Blanchard, J., Bonebrake, T. C., Chen, I. C., ... Falconi, L. (2017): Biodiversity redistribution under climate change: impacts on ecosystems and human well-being. - Science 355: eaai9214.

[44] Pinos, J., Studholme, A., Carabajo, A., Gracia, C. (2017): Leaf litterfall and decomposition of Polylepis reticulata in the treeline of the Ecuadorian Andes. Mountain Research and Development 37: 87-96.

[45] Ramsay, P., Oxley, E. (1997): The growth form composition of plant communities in the Ecuadorian páramos. - Plant Ecology 131: 173-192.

[46] Rangel Churio, J. O. (2000): Colombia. Diversidad Biótica III. The region of life Paramuna [Spanish]. Bogotá. - Universidad Nacional de Colombia, Bogotá.

[47] Robinson, C., Wookey, P., Parsons, A., Potter, J., Callaghan, T., Lee, J., Press, M., Welker, J. (1995): Responses of plant litter decomposition and nitrogen mineralisation to simulated environmental change in a high arctic polar semi-desert and a subarctic dwarf shrub heath. - Oikos 74: 503-512. 
[48] Röderstein, M., Hertel, D., Leuschner, C. (2005): Above-and below-ground litter production in three tropical montane forests in southern Ecuador. - Journal of Tropical Ecology 21: 483-492.

[49] Ruiz, D., Moreno, H. A., Gutiérrez, M. E., Zapata, P. A. (2008): Changing climate and endangered high mountain ecosystems in Colombia. - Science of the Total Environment 398: 122-132.

[50] Ruiz-Carrascal, D., Herzog, S., Guitierrez Lagoueyte, M., Gonzalez-Duque, D., CuevasMoreno, J., del Valle, J., Andreu-Hayles, L., Herrera, D., Martínez, R. (2017): Tropical andean ecosystems and the need to keep warming limits below a+ $1.5^{\circ} \mathrm{C}$ threshold. AGU Fall Meeting Abstracts GC53A-1886.

[51] Salinas, N., Malhi, Y., Meir, P., Silman, M., Roman Cuesta, R., Huaman, J., Salinas, D., Huaman, V., Gibaja, A., Mamani, M. (2011): The sensitivity of tropical leaf litter decomposition to temperature: results from a large-scale leaf translocation experiment along an elevation gradient in Peruvian forests. - New Phytologist 189: 967-977.

[52] Segnini, A., Posadas, A., Quiroz, R., Milori, D. M. B. P., Saab, S. C., Neto, L. M., Vaz, C. M. P. (2010): Spectroscopic assessment of soil organic matter in wetlands from the high Andes. - Soil Science Society of America Journal 74: 2246-2253.

[53] Shaw, M. R., Harte, J. (2001): Control of litter decomposition in a subalpine meadowsagebrush steppe ecotone under climate change. - Ecological Applications 11: 12061223.

[54] Smith, A. P. (1981): Growth and Population Dynamics of Espeletia (Compositae) in the Venezuelan Andes. - Smithsonian Institution Press, Washington.

[55] Smith, V., Bradford, M. (2003): Litter quality impacts on grassland litter decomposition are differently dependent on soil fauna across time. - Applied Soil Ecology 24: 197-203.

[56] Strickland, M. S., Keiser, A. D., Bradford, M. A. (2015): Climate history shapes contemporary leaf litter decomposition. - Biogeochemistry 122: 165-174.

[57] Ulyshen, M. D. (2016): Wood decomposition as influenced by invertebrates. - Biological Reviews 91: 70-85.

[58] Urban, M. C. (2015): Accelerating extinction risk from climate change. - Science 348: 571-573.

[59] Urbina, J. C., Benavides, J. C. (2015): Simulated small scale disturbances increase decomposition rates and facilitates invasive species encroachment in a high elevation tropical Andean peatland. - Biotropica 47: 143-151.

[60] Urrutia, R. B. (2008): Assessment of 21st century climate change projections in tropical South America and the tropical Andes. - Masters Thesis, University of Massachusetts Amherst, USA.

[61] Vuille, M., Bradley, R. S., Werner, M., Keimig, F. (2003): 20th century climate change in the tropical Andes: observations and model results. - Climate Variability and Change in High Elevation Regions: Past, Present \& Future: 75-99.

[62] Vuille, M., Francou, B., Wagnon, P., Juen, I., Kaser, G., Mark, B. G., Bradley, R. S. (2008): Climate change and tropical Andean glaciers: Past, present and future. - Earthscience reviews 89: 79-96.

[63] Wall, D. H., Bradford, M. A., St. John, M. J., Trofymow, J. A., Behan-Pelletier, V., Bignell, D. E., Dangerfield, J., Parton, W. J., Rusek, J. Voigt, W. (2008): Global decomposition experiment shows soil animal impacts on decomposition are climate dependent. - Global Change Biology 14: 2661-2677.

[64] Wang, T., Wang, G., Innes, J., Nitschke, C., Kang, H. (2016): Climatic niche models and their consensus projections for future climates for four major forest tree species in the Asia-Pacific region. - Forest Ecology and Management 360: 357-366.

[65] Zhang, D., Hui, D., Luo, Y., Zhou, G. (2008): Rates of litter decomposition in terrestrial ecosystems: global patterns and controlling factors. - Journal of Plant Ecology 1: 85-93. 


\section{APPENDIX}

Appendix 1. Studies about decomposition process in paramo ecosystems

\begin{tabular}{|c|c|c|c|c|}
\hline Authors & Year & Title & Conclusions & Decomposition \% \\
\hline Hofstede & 1995 & $\begin{array}{l}\text { The effects of } \\
\text { grazing and } \\
\text { burning on soil and } \\
\text { plant nutrient } \\
\text { concentrations in } \\
\text { Colombian paramo } \\
\text { grasslands. }\end{array}$ & $\begin{array}{l}\text { There is greater } \\
\text { decomposition in sites } \\
\text { with high affectation by } \\
\text { grazing and burning than } \\
\text { in sites without } \\
\text { disturbances. }\end{array}$ & $\begin{array}{l}\text { In areas without } \\
\text { disturbance, litter loss is } \\
\text { up to } 11.3 \pm 4.64 \% \text { per } \\
\text { year. While in areas } \\
\text { exposed to livestock and } \\
\text { fire, the decomposition } \\
\text { rate is } 34.3 \pm 8.03 \% \text { per } \\
\text { year. }\end{array}$ \\
\hline Chapela et al. & 2001 & $\begin{array}{l}\text { Ectomycorrhizal } \\
\text { fungi introduced } \\
\text { with exotic pine } \\
\text { plantations induce } \\
\text { soil carbon } \\
\text { depletion. }\end{array}$ & $\begin{array}{l}\text { Paramo soil with Pinus } \\
\text { radiata plantations } \\
\text { contain less carbon than } \\
\text { paramo grassland. It is } \\
\text { caused by the } \\
\text { introduction of } \\
\text { ectomycorrhizas in the } \\
\text { roots of the pines. }\end{array}$ & $\begin{array}{l}\text { The soil of the pine } \\
\text { plantations of } 10 \text { to } 20 \\
\text { years, show } 30 \% \text { less C } \\
\text { than soils of pasture } \\
\text { paramos. }\end{array}$ \\
\hline Coûteaux et al. & 2002 & $\begin{array}{l}\text { Decomposition of } \\
\text { standard plant } \\
\text { material along an } \\
\text { altitudinal transect } \\
\text { (65-3968 m) in the } \\
\text { tropical Andes. }\end{array}$ & $\begin{array}{l}\text { Decomposition rates } \\
\text { decrease along with } \\
\text { decreasing temperatures } \\
\text { (while altitude is higher). }\end{array}$ & $\begin{array}{c}\text { Five altitudes were } \\
\text { assessed: } 95,165,780, \\
1800,3400 \text { y } 3968 \mathrm{~m} \\
\text { a.s.l., carbon loss } \\
\text { percentage in the first } \\
\text { year was } 78.7,76.6,67.5 \text {, } \\
62.9,40.4 \text { and } 42.8 \\
\text { respectively. }\end{array}$ \\
\hline $\begin{array}{l}\text { Sarmiento and } \\
\text { Bottner }\end{array}$ & 2002 & $\begin{array}{c}\text { Carbon and } \\
\text { nitrogen dynamics } \\
\text { in two soils with } \\
\text { different fallow } \\
\text { times in the high } \\
\text { tropical Andes: } \\
\text { indications for } \\
\text { fertility restoration. }\end{array}$ & $\begin{array}{l}\text { In an agricultural area of } \\
\text { the Andean region above } \\
3000 \mathrm{~m} \text { a.s.l., } \\
\text { decomposition of straw } \\
\text { in a restored soil is } \\
\text { significantly faster than } \\
\text { in a degraded soil. }\end{array}$ & $\begin{array}{l}\text { Soil carbon loss was } \\
\text { expressed as the initial } \\
\text { percentage of 14C added } \\
\text { to the soil (mineralized). } \\
\text { The percentage of } \\
\text { mineralization of } 14 \mathrm{C} \\
\text { after } 12 \text { weeks of } \\
\text { incubation was } 43.9 \% \text { in } \\
\text { the restored soil and } \\
42.9 \% \text { in the degraded } \\
\text { soil. }\end{array}$ \\
\hline Pansu et al. & 2004 & $\begin{array}{l}\text { Comparison of five } \\
\text { soil organic matter } \\
\text { decomposition } \\
\text { models using data } \\
\text { from a } 14 \mathrm{C} \text { and } \\
15 \mathrm{~N} \text { labeling field } \\
\text { experiment. }\end{array}$ & $\begin{array}{l}\text { The best model of } \\
\text { organic matter } \\
\text { decomposition of soil } \\
\text { (MOMOS) uses kinetic } \\
\text { constants: three entries } \\
\text { of microbial biomass } \\
\text { MB and two MB outputs } \\
\text { mortality and respiration } \\
\text { constants. This model } \\
\text { significantly improved } \\
\text { the predictive quality and } \\
\text { robustness of MB-14C } \\
\text { and }-15 \mathrm{~N} \text { predictions. }\end{array}$ & $\begin{array}{c}\text { In } 720 \text { days, } 80 \% \text { of } 14 \mathrm{C} \\
\text { was lost in the analyzed } \\
\text { samples. This } \\
\text { decomposition percentage } \\
\text { was obtained in the five } \\
\text { models of soil organic } \\
\text { matter decomposition. }\end{array}$ \\
\hline
\end{tabular}




\begin{tabular}{|c|c|c|c|c|}
\hline Röderstein et al. & 2005 & $\begin{array}{l}\text { Above-and below- } \\
\text { ground litter } \\
\text { production in three } \\
\text { tropical montane } \\
\text { forests in southern } \\
\text { Ecuador. }\end{array}$ & $\begin{array}{l}\text { Decrease in temperature } \\
\text { while altitude increases, } \\
\text { influence the carbon } \\
\text { cycle of montane forests. } \\
\text { The decrease in } \\
\text { temperature along the } \\
\text { slope affects } \\
\text { decomposition. }\end{array}$ & $\begin{array}{l}\text { The litter mass decreased } \\
\text { to less than one third ( } 862 \\
\left.\text { to } 263 \mathrm{~g} \mathrm{~m}^{-2} \mathrm{y}^{-1}\right) \text { with } \\
\text { increasing altitudes ( } 1890 \\
\mathrm{~m} \text { to } 3060 \mathrm{~m}) \text {. While } \\
\text { litter production of fine } \\
\text { roots increased in an } \\
\text { approximated factor of } \\
\text { four }\left(506 \text { to } 2084 \mathrm{~g} \mathrm{~m}^{-2} \mathrm{y}^{-}\right. \\
1) .\end{array}$ \\
\hline Bottner et al. & 2006 & $\begin{array}{l}\text { Factors controlling } \\
\text { decomposition of } \\
\text { soil organic matter } \\
\text { in fallow systems } \\
\text { of the high tropical } \\
\text { Andes: a field } \\
\text { simulation } \\
\text { approach using } 14 \\
\text { C- and } 15 \mathrm{~N}- \\
\text { labelled plant } \\
\text { material. }\end{array}$ & $\begin{array}{l}\text { The relation between } \mathrm{C} \\
\text { and } \mathrm{N} \text { is determinant in } \\
\text { decomposition. If the } \\
\mathrm{C}: \mathrm{N} \text { relation in the plant } \\
\text { material increases, the } \\
\text { decomposition rate } \\
\text { decreases and the } \\
\text { mortality of the } \\
\text { microbial biomass } \\
\text { increases. }\end{array}$ & $\begin{array}{l}\text { For N-rich plant material } \\
(\mathrm{N}+\text { treatment), the total } \\
\text { of } 14 \mathrm{C} \text { remaining at the } \\
\text { end of the experiment } \\
\text { was similar in the } \\
\text { Gavidia paramo and in } \\
\text { Puna de Patacamaya: } \\
25 \% \text { of the initial } 14 \mathrm{C} \text {. }\end{array}$ \\
\hline Pansu et al. & 2007 & $\begin{array}{l}\text { Modelling the } \\
\text { transformations } \\
\text { and sequestration } \\
\text { of soil organic } \\
\text { matter in two } \\
\text { contrasting } \\
\text { ecosystems of the } \\
\text { Andes. }\end{array}$ & $\begin{array}{l}\text { The dynamics of } 14 \mathrm{C} \\
\text { and } 15 \mathrm{~N} \text { were very } \\
\text { different in the two } \\
\text { systems. In the puna, the } \\
\text { transformation processes } \\
\text { stop during the long dry } \\
\text { periods, although the } \\
\text { annual total } \\
\text { mineralization is greater } \\
\text { than in paramo. }\end{array}$ & $\begin{array}{l}\text { In dry puna, the } 66 \% \text { of } \\
\text { the } 14 \mathrm{C} \text { initially added } \\
\text { was mineralized during } \\
\text { the first wet season (first } \\
120 \text { days). Subsequently, } \\
\text { the mineralization was } \\
\text { almost paralyzed until the } \\
\text { end of the dry season (on } \\
\text { day } 400 \text { ), then } 73 \% \text { of the } \\
\text { aggregate } 14 \mathrm{C} \text { was } \\
\text { mineralized after the } \\
\text { second wet season (on } \\
\text { day } 500 \text { ) and } 75 \% \text { on day } \\
690 \text { after the first rain that } \\
\text { followed the last long dry } \\
\text { period. In humid paramo, } \\
\text { only } 42 \% \text { of the } 14 \mathrm{C} \\
\text { added was mineralized } \\
\text { during the initial phase of } \\
\text { the process, then } \\
\text { mineralization progressed } \\
\text { slowly, until } \\
\text { approximately } 65 \% \text { of the } \\
14 \mathrm{C} \text { was mineralized } \\
\text { after } 1 \text { year, and the } 75 \% \\
\text { after } 2 \text { years. }\end{array}$ \\
\hline Martinez et al. & 2007 & $\begin{array}{c}\text { Succession pattern } \\
\text { of carrion-feeding } \\
\text { insects in Paramo, } \\
\text { Colombia. }\end{array}$ & $\begin{array}{l}\text { The succession of } \\
\text { scavenger insects can be } \\
\text { an indicator of the state } \\
\text { of decomposition and the } \\
\text { time elapsed after an } \\
\text { organism death. }\end{array}$ & $\begin{array}{l}\text { After } 83 \text { days, } 83 \% \text { of the } \\
\text { initial weight of Sus } \\
\text { scrofa corpse had been } \\
\text { lost. Five stages of } \\
\text { decomposition were } \\
\text { identified with indicator } \\
\text { species: Calliphora } \\
\text { nigribasis in the fresh }\end{array}$ \\
\hline
\end{tabular}




\begin{tabular}{|c|c|c|c|c|}
\hline & & & & $\begin{array}{l}\text { stage; Compsomyiops } \\
\text { verena in the swollen } \\
\text { stage; Compsomyiops } \\
\text { Bolivian during active } \\
\text { decomposition; Stearibia } \\
\text { nigriceps and Hydrotaea } \\
\text { sp. during the advanced } \\
\text { decay and Leptocera sp. } \\
\text { for dry remains. }\end{array}$ \\
\hline Garrido & 2011 & $\begin{array}{l}\text { Study on radial } \\
\text { growth, exchange } \\
\text { and leaf } \\
\text { decomposition of } \\
\text { three Polylepis } \\
\text { species (Rosaceae) } \\
\text { in two locations of } \\
\text { the Ecuadorian } \\
\text { Andes. }\end{array}$ & $\begin{array}{l}\text { There is a highly } \\
\text { significant difference } \\
\text { among species. Polylepis } \\
\text { reticulata had the least } \\
\text { decomposition, } \\
\text { attributed to climatic } \\
\text { conditions as soil } \\
\text { moisture and } \\
\text { temperature, since they } \\
\text { are better predictors of } \\
\text { decomposition than } \\
\text { quality of its organic } \\
\text { matter. }\end{array}$ & $\begin{array}{l}\text { The global average for } \\
\text { the remaining biomass } \\
\text { percentage of leaf } \\
\text { decomposition is } 75.44 \% \text {. } \\
\text { P. reticulata shows a } \\
\text { lower decomposition with } \\
\text { a mean of } 86.67+ \\
7.015 \% \text { Standard } \\
\text { deviation (D.E.), P. } \\
\text { pattern shows an average } \\
\text { of } 75.809+12.183 \% \\
\text { D.E. and P. incana had a } \\
\text { greater decomposition } \\
\text { with an average of } 63.83 \\
+16.467 \% \text { D.E. }\end{array}$ \\
\hline Ibrahim et al. & 2015 & $\begin{array}{l}\text { Modelling carbon } \\
\text { turnover through } \\
\text { the microbial } \\
\text { biomass in soil. }\end{array}$ & $\begin{array}{l}\text { Comparison of } \\
\text { predictions with } \\
\text { collected data in the field } \\
\text { showed that the model is } \\
\text { capable of simulating } \\
\text { transformations and } \\
\text { movement (plant-soil- } \\
\text { atmosphere) of the } \\
\text { carbon depending on the } \\
\text { parameters previously } \\
\text { defined }\end{array}$ & $\begin{array}{l}\text { The predictions of the } \\
\text { model showed a higher } \\
\text { microbial content of C } \\
\text { and a higher microbial } \\
\text { respiration activity in the } \\
\text { wheat plots than in vean } \\
\text { plots. The metabolic } \\
\text { coefficient (mg } \mathrm{CO}^{2} / \mathrm{g} \\
\text { MB C) after } 9 \text { months } \\
\text { was } 0.04 \text { in wheat and } \\
0.025 \text { in bean. }\end{array}$ \\
\hline $\begin{array}{l}\text { Urbina and } \\
\text { Benavides }\end{array}$ & 2015 & $\begin{array}{l}\text { Simulated small } \\
\text { scale disturbances } \\
\text { increase } \\
\text { decomposition } \\
\text { rates and facilitates } \\
\text { invasive species } \\
\text { encroachment in a } \\
\text { high elevation } \\
\text { tropical Andean } \\
\text { peatland. }\end{array}$ & $\begin{array}{l}\text { Decomposition rate in } \\
\text { soil surface }(0-10 \mathrm{~cm}) \\
\text { triples in fertilized soils } \\
\text { with physical } \\
\text { disturbances in } \\
\text { comparison with the } \\
\text { control (soil without } \\
\text { additions of foreign } \\
\text { materials or physical } \\
\text { disturbances). }\end{array}$ & $\begin{array}{l}\text { Decomposition rate in the } \\
\text { control was } 0.09 \pm 0.001 \\
\text { and in the plots with } \\
\text { fertilized soils with } \\
\text { physical disturbances was } \\
\quad 0.25 \pm 0.005 \text {. }\end{array}$ \\
\hline Pinos et al. & 2017 & $\begin{array}{l}\text { Leaf litterfall and } \\
\text { decomposition of } \\
\text { polylepis reticulata } \\
\text { in the treeline of } \\
\text { the Ecuadorian } \\
\text { Andes. }\end{array}$ & $\begin{array}{l}\text { Temperature was one of } \\
\text { the main regulators for } \\
\text { decomposition rates of } \\
\text { litter. Humidity was not } \\
\text { controlled, then it is not } \\
\text { a limiting factor in } \\
\text { decomposition. }\end{array}$ & $\begin{array}{l}\text { Decomposition rate of } \\
\text { litter of Polylepis } \\
\text { reticulata was } 0.38 \pm 0.02 \\
\text { per year. The study was } \\
\text { conducted in an } \\
\text { altitudinal range of } 3700 \\
\text { to } 3900 \text { m a.s.l. }\end{array}$ \\
\hline
\end{tabular}


Appendix 2. Studies about the effect of climate change in decomposition process in paramo ecosystem

\begin{tabular}{|c|c|c|c|c|}
\hline Authors & Year & Title & Conclusions & Decomposition \% \\
\hline Salinas et al. & 2011 & $\begin{array}{l}\text { The sensitivity of } \\
\text { tropical leaf litter } \\
\text { decomposition to } \\
\text { temperature: results from } \\
\text { a large-scale leaf } \\
\text { translocation experiment } \\
\text { along an elevation } \\
\text { gradient in Peruvian } \\
\text { forests. }\end{array}$ & $\begin{array}{c}\text { When samples were } \\
\text { grouped between species } \\
\text { and elevations, soil } \\
\text { temperature explained } \\
\text { 95\% of the variation in } \\
\text { the rate of } \\
\text { decomposition, but no } \\
\text { direct relation with soil } \\
\text { humidity or precipitation } \\
\text { was observed. }\end{array}$ & $\begin{array}{l}\text { Heating of } 0.9^{\circ} \mathrm{C} \text { in the } \\
\text { last decades could have } \\
\text { increased decomposition } \\
\text { and mineralization rates } \\
\text { of nutrients by } 10 \% \text {. }\end{array}$ \\
\hline Espín & 2012 & $\begin{array}{c}\text { Altitudinal patterns of } \\
\text { litter decomposition in } \\
\text { two paramo localities } \\
\text { with different climatic } \\
\text { regimes. }\end{array}$ & $\begin{array}{l}\text { Using an altitudinal } \\
\text { gradient to outline } \\
\text { possible in situ scenarios } \\
\text { on climate change is } \\
\text { valid. It is useful to } \\
\text { determine that there is a } \\
\text { strong relation between } \\
\text { temperature and } \\
\text { decomposition rate in the } \\
\text { Andean paramo. }\end{array}$ & $\begin{array}{l}\text { Decomposition rates of } \\
\text { litter could increase up to } \\
5 \% \text { per year with every } \\
1{ }^{\circ} \mathrm{C} \text { additional average } \\
\text { diurnal temperature. }\end{array}$ \\
\hline Salcedo & 2014 & $\begin{array}{l}\text { Effects of the increasing } \\
\text { temperatures and fires on } \\
\text { Mesofauna (Arthropods) } \\
\text { of the Soil and the } \\
\text { Decomposition of Litter } \\
\text { in a paramo Ecosystem } \\
\text { in the North of Ecuador. }\end{array}$ & $\begin{array}{l}\text { In a cold ecosystem such } \\
\text { as paramo, an increase in } \\
\text { temperature could be } \\
\text { expected to determine } \\
\text { greater decomposition of } \\
\text { litter; however, the } \\
\text { results of the study } \\
\text { showed an opposite } \\
\text { pattern, perhaps as a } \\
\text { result of a decrease, at } \\
\text { least temporarily, in the } \\
\text { moisture content of the } \\
\text { ground. }\end{array}$ & $\begin{array}{l}\text { Decomposition rate in } \\
\text { the treatments that were } \\
\text { heated with cameras } \\
\text { (which increased the } \\
\text { temperature between } \\
0.89^{\circ} \mathrm{C} \text { and } 2.06{ }^{\circ} \mathrm{C} \text { in } \\
\text { the day and between } \\
0.66^{\circ} \mathrm{C} \text { and } 0.86^{\circ} \mathrm{C} \text { at } \\
\text { night) They were } \\
\text { between } 3 \text { and } 4 \% \\
\text { slower than treatments } \\
\text { that were not heated with } \\
\text { cameras. The treatment } \\
\text { with the slowest } \\
\text { decomposition was } \\
\text { camera/burning ( } 54.5 \% \\
\pm 1.38 \text { ), while the } \\
\text { highest decomposition } \\
\text { was recorded in the plots } \\
\text { with the control } \\
\text { treatment ( } 49.7 \% \pm 1.2 \text { ). }\end{array}$ \\
\hline $\begin{array}{l}\text { Looby and } \\
\text { Treseder }\end{array}$ & 2018 & $\begin{array}{l}\text { Shifts in soil fungi and } \\
\text { extracellular enzyme } \\
\text { activity with simulated } \\
\text { climate change in a } \\
\text { tropical montane cloud } \\
\text { forest. }\end{array}$ & $\begin{array}{l}\text { Fungi abundance and } \\
\text { alpha diversity increased } \\
\text { significantly with } \\
\text { warmer temperatures and } \\
\text { drier conditions. } \\
\text { Concerning composition } \\
\text { of fungal community, it } \\
\text { showed a change with } \\
\text { increasing temperatures }\end{array}$ & $\begin{array}{l}\text { With a } 4{ }^{\circ} \mathrm{C} \text { increase and } \\
20 \% \text { of humidity } \\
\text { decrease, fungal } \\
\text { abundance and richness } \\
\text { grew in } 50 \% \text {. }\end{array}$ \\
\hline
\end{tabular}




\begin{tabular}{l|c|c|c}
\hline & & F $=4.31, \mathrm{R} 2=0.170$, \\
$\mathrm{P}<0.001)$ and \\
decreasing humidity $(\mathrm{F}=$ \\
$4.30, \mathrm{R} 2=0.170$, \\
$\mathrm{P}<0.001)$. Alterations in \\
the composition of the \\
community was \\
associated with changes \\
in the richness of certain \\
fungal phylum. There \\
was a general increase in \\
Ascomycota richness \\
with warmer \\
temperatures and drier \\
conditions. While, the \\
richness of \\
Cryptomycota decreased \\
in translocated soils to \\
warmer and drier \\
conditions.
\end{tabular}

